\title{
REGULATION OF FREEDOM OF ACCESS TO ENVIRONMENTAL INFORMATION IN THE LEGISLATION OF THE EUROPEAN UNION AND UKRAINE
}

\section{Kachuriner V. L.}

\section{INTRODUCTION}

In the 21st century, mankind faced specific threats to the environment due to air, water and soil pollution, reduced species biodiversity and climate change. These trends contribute to the creation of an appropriate legal framework and to greater accountability for environmental pollution. Thus, environmental protection has become the subject of numerous national, supranational and international legal norms. In addition, international environmental activities cannot be considered separately from related economic issues and social problems. Environmental protection is now a key issue on the political agenda and an important problem, both at national and European and international levels.

The global nature of environmental problems necessitates the further development of international environmental law as a legal basis for international environmental cooperation. Environmental concepts, standards and principles are usually specified in regional and bilateral agreements, and detailed regulation is carried out at national level, as appropriate. However, European Union law has a particularly significant impact on both international and national environmental law. The most intensive national and international regulation of environmental protection is carried out on the European continent, and the most successful environmental problem is solved in the context of European integration. This is evidenced by the legal experience of implementing environmental policy at both the European Union and Member States level.

Environmental protection is one of the priority areas of the European Union's activities, which defines the EU's competence in the field of environmental protection and causes the adoption of a large number of panEuropean regulations. The development of European environmental law is characterized by the search for optimal approaches to solving complex problems of natural resource management. Thus, in the Association Agreement between Ukraine and the European Union, Article 360-366 of 
Section V, "Economic and Sectoral Cooperation"1 ${ }^{1}$, is devoted to the environment itself. The Parties to the Agreement cooperate on environmental issues and thus contribute to the achievement of the goals of sustainable development and the "green economy". Analysis of EU environmental legislation is essential to further improve and improve the effectiveness of environmental legislation in Ukraine. The priority of Ukraine's cooperation with the European Union will be of practical importance achieving the goal of improving the level of production productivity, expanding its base of economic growth and competitiveness, studying and introducing experience and basic developments in the field of environmental human rights and citizens. It is advisable to draw attention to the various doctrinal developments in the field of protection of environmental human rights, both in general in the EU legal system and in respect of a particular type of rights, the right to access environmental information.

In recent years, many EU environmental law researchers have put on the agenda the question of whether national laws of EU Member States, as well as EU unified law, have sufficient legal basis to protect the interests of society against the dangers of environmental problems, or to seek additional guarantees of respect for the fundamental right of the individual - the right to a clean environment.

\section{The principle of access to environmental information}

\section{in international law}

The interdependence of environmental protection, peace, human rights and freedoms was first reflected in the Stockholm Declaration of $1972^{2}$. This principle was subsequently developed and substantially supplemented in other international instruments. In particular, the next step in the development of citizens' environmental rights in international law was the UN Conference on Environment and Development, held in June 1992 in Rio de Janeiro, which adopted a number of important international instruments ${ }^{3}$, in including the Declaration and Agenda for the 21st Century. The 21st Century Agenda, which is the plan of action of the

1 Угода про асоціацію між Україною, з однієї сторони, та Європейським Союзом, Європейським Співтовариством 3 атомної енергії і їнніми державами-членами, 3 іншої сторони. URL : http://www.kmu.gov.ua/control/publish/article?art_id=246581344.

2 Декларация Конференции Организации Объединенных Наций по проблемам окружающей человека среды 1972 г. URL: http://www.un.org/ru/documents/decl_conv/ declarations/declarathenv.shtml.

${ }^{3}$ Доклад Конференции Организации Объединенных Наций по окружающей среде и развитию Рио-де-Жанейро, 3-14 июня 1992 года A/CONF.151/26/Rev.1 (Vol. I). Нью-Йорк : Организация Объединенных Наций. 1993. С. 7-8. 
International Community for Environment and Sustainable Development, states that environmental issues are addressed with the participation of all concerned citizens. States contribute to informing society by providing widespread access to environmental information. At the 3rd Sofia Conference of Ministers of the Environment of Europe in 1995, guidelines for access to environmental information were adopted. In June 1998, at the 4th Conference of Ministers of the Environment, held in Aarhus (Denmark), 35 countries of Europe signed the Convention on Access to Information, Public Participation in Decision-making and Access to Justice in Environmental Matters ${ }^{4}$ which was subsequently ratified by both the European Union and Ukraine, and therefore a further analysis of the provisions of this Convention is common to both the EU and Ukraine. Paragraph 3 of Art. 2 of the Aarhus Convention lists the information that should be considered environmental. So, this is information about: the state of the components of the environment and their interaction: the state of the atmosphere and the air, the state of water, the state of the soil, the state of landscapes, the state of natural objects, biological diversity and its components, including genetically modified organisms; factors that influence or are capable of affecting the components of the environment: substances, energy, noise, radiation; activities that affect or may affect environmental components; measures that affect or may affect environmental components: administrative measures, environmental agreements, environmental policy, legislation, plans, programs, justifications for environmental decisions; cost-benefit analysis and other economic analysis and assumptions used in the environmental decision-making process; the state of health and safety of people, living conditions, the state of objects of culture and structures to the extent that they are affected or may be affected by the state of the environmental components ${ }^{5}$.

On 17 February 2005, the Council of the European Union signed the Decision $^{6}$ which adopted the Aarhus Convention. The convention is based on the assertion that better awareness and involvement of the public in environmental issues will help to strengthen the environment. The purpose

\footnotetext{
${ }^{4}$ Конвенція ООН про доступ до інформації, участь громадськості в процесі прийняття рішень та доступ до правосуддя з питань, що стосуються довкілля (Орхуська Конвенція) : Міжнародний документ від 25.06.1998. URL: http://www.unece.org (ECE/CEP/43).

${ }^{5}$ Правове регулювання відносин в сфері довкілля в Європейському Союзі та в Україні / За заг. ред. В.Г. Дідика. К., 2007. С. 98.

${ }^{6}$ Council Decision 2005/370 of 17 February 2005 on the conclusion, on behalf of the European Community, of the Convention on access to information, public participation in decision-making and access to justice in environmental matters Convention on access to information, public participation in decision-making and access to justice in environmental matters. Official Journal. 2005. L 124. P. 1-20.
} 
of the Convention is to promote the protection of every person of the present and future generations to live in an environment conducive to health and well-being. By signing the Convention, its Parties have declared that each Party guarantees the right to access to information, to public participation in decision-making and to access to justice in environmental matters, without discrimination on grounds of nationality, nationality or place of residence, and in the case of a legal person, without discrimination on the basis of its registered location or actual center of business.

Drawing on the main provisions of the Aarhus Convention, we can conclude that the Convention is based on three fundamental principles that are closely related.

1. The principle of access to environmental information. The Convention gives a broad concept of environmental information that covers not only the state of environmental components such as air, water, soil, landscape, biological species, including genetically modified organisms; but also such factors as energy, noise and radiation, as well as activities or activities, including administrative measures, environmental agreements, policies, legislation, plans and programs that affect or may affect environmental components, economic analysis data; health and safety of people, their living conditions; the status of cultural objects to the extent that they are or may be affected by the state of the environment. It is important that the information can be obtained without justification for the interest of having it, and in the form in which it is requested, and as soon as possible, but no later than four weeks. The applicant should be informed of any extension of the deadlines and the reasons for this. The Convention sets out the grounds for refusing to provide information, including the obviousness of the unreasonableness or non-formulation of the request and/or incompleteness of the requested material. A request for environmental information may also be refused if its disclosure could adversely affect the confidentiality of public authorities, international relations, national defense or public security, the administration of justice, the confidentiality of commercial and industrial information, personal data, intellectual property rights, etc. Information on harmful emissions into the environment may not be confidential. In cases where there is a threat to the environment or human health as a result of its activities or due to natural phenomena, all information that could enable the public to take measures to prevent or reduce harm should be disseminated immediately. States should ensure that public authorities have at their disposal environmental information pertaining to their type of activity and that mandatory systems are in place to ensure that public authorities receive appropriate information on planned and implemented activities that could 
have a significant environmental impact. Parties to the Convention should organize lists, registers or archives, and provide free access to the public. Each of the countries that have acceded to the Convention should ensure a gradual increase of information in electronic databases, which should be easily accessible to the general public. In accordance with the provisions of the Convention, information available through public communications networks to the general public should include, inter alia: environmental reports, texts of environmental legislation, policy documents, plans and programs, related to the environment or related environmental protection agreements and other information that may facilitate the application of national law to comply with the provisions of the Convention.

2. The principle of public participation in decision-making. The concerned public should be adequately, timely and effectively informed of environmental decisions of the authorities. In particular, under the Convention, it is information on the type of activity to be decided, the nature of such decisions, the procedure, time and place of their adoption, as well as the public authority responsible for decision-making and, most importantly, the possibility of public participation in making the above decisions. However, in order to ensure the most effective public participation in the environmental decision-making process, the provisions of the Convention provide for the need to provide the public with sufficient information for the time being. With regard to public participation in decision-making on specific activities that have or may have an environmental impact, it should be noted that under the Convention, the public authorities of each Party, in accordance with national law, provide the public concerned with free access to all information regarding a particular question. The Convention also provides a list of components that should include such information, including a description of the industrial site, a description of the most significant environmental factors, a description of measures to prevent or reduce such an impact, consideration of the main alternatives considered by the applicant and more. The Annex to the Convention provides a list of activities that may affect the environment and which the public has the right to participate in. The public participation process gives her the opportunity, during open hearings or consideration of such matters, to comment and to comment in writing or otherwise. In doing so, each country, in accordance with the provisions of the Convention, provides the conditions under which the results of public participation would be duly taken into account in the decision. Particular attention should be paid to the fact that, under the Convention, it is possible for the public to participate in the preparation of executive acts and / or generally binding legal acts that can significantly 
affect the environment. In order to ensure this, the most important is among other activities, namely, the public is given the opportunity to express their comments directly or through representative advisory bodies. The results of public participation are taken into account as much as possible.

3. The principle of access to justice. Any citizen who believes that his or her right to information or to participate in the decision-making process has been violated may challenge the decision in a court or other independent and impartial body. The Convention requires that the review of the decision in court be expeditious and would not require payment or that such payment would be low. Decisions taken by the court are binding on the public authority that has the relevant information. Relevant representatives of the concerned public who are either sufficiently interested or believe that a violation has occurred have access to justice. The presence of interest, as the suitability of public organizations to certain criteria, is determined in accordance with national law. However, the aforementioned provisions of the Convention do not preclude the use of a preliminary dispute settlement procedure by an appropriate administrative authority where such procedure is provided for in national law. States Parties to the Convention must provide effective remedies, including injunctive relief, fair, impartial, timely and cost-free ${ }^{7}$. The Convention declared that the parties should consider establishing mechanisms to eliminate or mitigate financial and other obstacles to justice. Such mechanisms are the least prepared for implementation in Ukraine. Undoubtedly, the Aarhus Convention today is the most important document that aims at securing and realizing the environmental rights of everyone. However, it should be noted that the first steps towards the adoption of important regulations in the field of environmental rights protection, in particular the right of access to environmental information, which is now the first of the principles on which the Aarhus Convention is based, were implemented by the European Union long before the Convention was approved.

\section{The right to access environmental information in EU legislation}

Directive 2003/4/EC was signed in order to provide the parties with a single, clear and comprehensive legislative text regarding public access to environmental information. In addition, it was declared that the provisions of the Directive should comply with the Aarhus Convention in connection with the signing of the latter by the European Community.

7 Добробог Л.М. Інформаційне забезпечення реалізації прав людини на екологічну безпеку. URL: http://www-history.univer.kharkov.ua. 
The purpose of Directive 2003/4/EC is to guarantee the right of access to environmental information and to ensure the systematic and broadening of the boundaries of dissemination of environmental information to the public $^{8}$. For this purpose, the Directive provides for the use of computer telecommunications and / or electronic technologies. To this end, States Parties shall take all necessary measures to ensure that public authorities have access to environmental information and to further disseminate such information through computer telecommunications and / or electronic technology, if available. According to the Directive, the information to be made available is, in particular: the texts of international agreements, conventions and agreements of the Community, national, regional and local legislation in the field of the environment; public policies, programs and plans for the environment; State reports on the state of the environment (to be published at least every 4 years); data on actions that affect the environment and more.

In accordance with the provisions of Directive 2003/4/EC, Member States should guarantee the accessibility and openness of environmental information held by a public authority or a public authority to any person requesting it. In this case, the requesting person does not need to formulate his/her interest. In order to comply with the guarantees above, the Parties are obliged to ensure that: officials support the public in accessing information; the list of public authorities was made available to the general public; practical measures have been identified to enable the effective exercise of the right of access to environmental information. Some innovation is that Member States ensure that public authorities properly inform the public about the rights they enjoy under this Directive and provide information and advice to that effect. However, Directive 2003/4/EC provides that, where the request is very broadly formulated, the public authority asks the person to clarify the request and helps him to do so, in particular by providing information on the use of public registers. The Directive provides for cases where requests for environmental information may be rejected, which generally comply with the provisions of the Aarhus Convention. At the same time, it is noted that in each case, public authorities should compare the public interest in disclosure and the interest that is the basis for refusal (to set priorities). The directive prohibits the rejection of a request if it is related to environmental information.

\footnotetext{
${ }^{8}$ Directive 2003/4/EC of the European Parliament and of the Council of 28 January 2003 on public access to environmental information and repealing Council Directive 90/313/EEC. Official Journal. 2003. L 041. P. 26-32.
} 
As regards the payment of environmental information, the Directive provides that the relevant public authorities may impose a fee for the provision of any information, but such a fee should not exceed a reasonable amount. At the same time, the rates of such payment should be published, as well as information on the conditions under which the fee may be charged. Much of Directive 2003/4/EC is devoted to one of the three fundamental principles on which the Aarhus Convention is based, namely, the principle of "public access to justice". In accordance with the provisions of the Directive, Member States shall ensure that any requesting person who considers that his or her request for information has been ignored, for which the request was incorrectly rejected (in whole or in part), or received or incorrectly answered the request was not considered in accordance with the provisions of the Directive, had access to a procedure for reviewing actions or omissions by this or other public authority or administrative review by an independent and impartial body established by law. The provisions of the Directive on the speed and free (moderation of payment) of such review are also fully in line with the Aarhus Convention. In addition to the review procedure, Member States should ensure that the requesting person has access to the review procedure by a court or any other independent and impartial body established by law, which may consider the actions or omissions of the relevant public authorities, and decisions of which may be final. In this case, the final decisions are binding on the executing public authority. Member States are also allowed to provide that third parties accused of disclosing information also have access to legal redress. Directive 2003/4/EC regulates the obligation for Member States to ensure that information is not outdated, accurate and comparable.

Case law already has 541 cases brought to light in the light of Directive 2003/4/EC ${ }^{9}$. Computer telecommunications and / or electronic equipment are used for this purpose. L. Kremer points out that as of 2007, the European Court of Justice had issued around 400 decisions. He is trying to interpret modern environmental law ecologically friendly and to strengthen the environment ${ }^{10}$. In his work, A.L. Dubovyk gives a report to the judge

${ }^{9}$ Reference for a preliminary ruling from the Najvyšší súd Slovenskej republiky (Slovak Republic) lodged on 23 August 2010 - Jozef Križan and Others v Slovenská inšpekcia životného prostredia. Official Journal. 2010. C 301. P. 11-12; Reference for a preliminary ruling from the Tribunal administratif de Paris (France) lodged on 12 November 2009 - Ville de Lyon v Caisse des dépôts et consignations. Official Journal. 2010. C 37. P. 29; Request for a preliminary ruling from the Unabhängiger Verwaltungssenat Wien (Austria) lodged on 17 June 2013 - Ferdinand Stefan. Official Journal. 2013. C. 274. P. 2-3.

10 Кремер Л., Винтер Г. Экологическое право Европейского Союзу / отв. ред. О.Л. Дубовик. М. : Городец, 2007. С. 40. 
of the Belgian Constitutional Court, L. Lavriesen, whom he delivered at a conference entitled "30 Years of EU Environmental Law" and emphasized that: "In the years of its activity, the Court of Justice has developed a series of general doctrines that have fostered efficiency. European law in general. These doctrines are also important for the development of environmental European law"11 ${ }^{11}$ However, in its decisions it establishes only the right, or more precisely, the competence of Union bodies to regulate any sphere, until the obligation to take measures based on the principles and aspects of environmental policy has been established in court. However, it is necessary to interpret the contents of these general provisions with some caution, since only the core of this program of obligations is protected by judicial protection. Anything that goes beyond this is subject to the legislature. L. Lavriesen emphasizes: "Since 7 February 1985, when the judgment in the L'Association de defense de brulenrs $d$ huiles usages was decided, the Court recognizes that environmental protection is a "mandate requirement" which, in the absence of full harmonization legislation may justify the use of measures restricting trade in Member States"12.

Directive 2003/35/EC promotes the providing for public participation in respect of the drawing up of certain plans and programmes relating to the environment and amending with regard to public participation and access to justice ${ }^{13}$. Member States shall enable the public to participate in the preparation and modification, revision of plans or programs. To this end, the following should be ensured: informing the public, either by public announcement or by other appropriate means, of such plans or programs; the public has the right to comment and decide on plans and programs; in making these decisions, due account should be taken of the results of public participation; having considered the comments and opinions expressed by the public, the competent authority shall use its best endeavors to inform the public of the decision and the reasons and considerations on which these decisions are based, including information on the public participation process.

11 Дубовик О.Л. Экологическое право ЕС: формирование, развитие, достижения и актуальные задачи. Право и политика. 2004. № 12. С. 65.

${ }^{12}$ Степаненко В.С. Понятие и правовое значение принципов экологической политики ЕС. Политика и общество : Научный гуманитарный журнал. 2006. № 6. С. 91-92.

${ }^{13}$ Directive 2003/35/EC of the European Parliament and of the Council of 26 May 2003 providing for public participation in respect of the drawing up of certain plans and programmes relating to the environment and amending with regard to public participation and access to justice Council Directives 85/337/EEC and 96/61/EC - Statement by the Commission. Official Journal. 2003. L 156. P. 17-25. 
Undoubtedly, the layer of EU uniform legislation on the protection of environmental information rights is much wider. However, the directives mentioned are groundbreaking, because they laid the foundations for further development of EU law in this area.

\section{Legislation of Ukraine in the field of access to environmental information}

Regarding the legislative and regulatory acts of Ukraine governing the legal relations in the field of access to environmental information such as the Constitution of Ukraine, the Law of Ukraine "On Information"14 of 02.10.1992, the Law of Ukraine "On Environmental Protection"15 of 25.06.1991, Law of Ukraine "Fundamentals of Legislation on Health Care" $^{16}$ of 19.11.1992, Law of Ukraine "On Ensuring Sanitary and Epidemic Well-Being of the Population" ${ }^{17}$ of 24.02 .1994 , Law of Ukraine "On Nuclear Energy Use and Radiation Safety" ${ }^{18}$ vi 02/02/1995, Law of Ukraine "On Ratification of the Convention on Access to Information, Public Participation in Decision-Making and Access to Justice in Environmental Matters"19 of 06.07.1999, Law of Ukraine "On Environmental Expertise" $^{20}$ dated 9 February 1995 and others.

Environmental information plays a leading role in environmental security. First of all, such information is necessary for the preparation and adoption of economic, management and other decisions, the implementation of which is associated with the negative impact of human activity on the environment. Environmental information can be used by citizens to protect their environmental rights, as well as a basis for interfering with unsatisfactory environmental activities of the state, business structures, especially if the latter do not fulfill the tasks assigned to them by law. In Ukraine, the definition of "information" is enshrined in

${ }^{14}$ Про інформацію : Закон України від 02.10.1992 № 2657-XII. Відомості Верховної Ради Украӥни. 1992. № 48. Ст. 650.

15 Про охорону навколишнього природного середовища : Закон від 25.06.1991 № 1264-ХІІ. Відомості Верховної Ради Украӥни. 1991. № 41. Ст. 546.

16 Основи законодавства України про охорону здоров'я : Закон від 19.11.1992 № 2801-XII. Відомості Верховної Ради України. 1993. № 4. Ст. 19.

${ }^{17}$ Про забезпечення санітарного та епідемічного благополуччя населення : Закон від 24.02.1994 № 4004-XII. Відомості Верховної Ради України. 1994. № 27. Ст. 218.

18 Про використання ядерної енергії та радіаційну безпеку : Закон від 08.02.1995 № 39/95-ВР. Відомості Верховної Ради Украӥни. 1995. № 12. Ст. 81.

${ }^{19}$ Про ратифікацію Конвенції про доступ до інформації, участь громадськості в процесі прийняття рішень та доступ до правосуддя 3 питань, що стосуються довкілля : Закон України від 6 липня 1999 року № 832-XIV. Офіційний вісник Украӥни. 1999. № 28. Ст. 2.

${ }^{20}$ Про екологічну експертизу : Закон від 09.02.1995 № 45/95-ВР. Відомості Верховної Ради України. 1995. № 8. Ст. 54. 
a number of legislative acts. However, the most general definition covering all types of information is provided in the Law of Ukraine "On Information". According to this Law, information is the documented or publicly announced information about events and phenomena occurring in society and the state and the environment. The classification of information at the legislative level is also enshrined in the Law of Ukraine "On Information", which refers not only to types of information but also to its industry. Article 3 of the aforementioned law establishes the obligation of the state to constantly ensure the timely creation, proper functioning and development of information systems, networks, banks and databases in all areas of information activities, which fully complies with the obligation established by Directive 2003/4/EC ${ }^{21}$. Member States shall take all necessary measures to ensure that the relevant public authorities have access to the information and that such information is systematic, accurate and up-to-date. The state guarantees freedom of information activities in these areas to all citizens and legal entities within the limits of their rights and freedoms, functions and powers. In general, the country has a well-developed system of regulations on the collection, accumulation, dissemination and access to environmental information. Among these are, in particular, the Law of Ukraine "Fundamentals of Healthcare Legislation" $^{22}$, since environmental status is known to be an important factor affecting human health. The Law stipulates that one of the main means of ensuring the right of citizens to health protection from adverse environmental impact is the right of a person to have accurate and timely information about the state of their health and the health of the population, including existing or possible risk factors and their degree.

All the above-mentioned provisions of the Acts implement the principle of the Aarhus Convention on Public Access to Environmental Information, and also comply with the provisions of a number of EU Directives. However, the most important and substantive rules on the subject under investigation are usually contained in the Constitution of Ukraine. The constitutional norm of part two of Art. $34^{23}$, which enshrines the right to information, includes the ability to collect, store, use and disseminate any information orally, in writing or otherwise, at its

${ }^{21}$ Directive 2003/4/EC of the European Parliament and of the Council of 28 January 2003 on public access to environmental information and repealing Council Directive 90/313/EEC. Official Journal. 2003. L 041. P. 26-3.2

${ }^{22}$ Основи законодавства України про охорону здоров’я : Закон від 19.11.1992 № 2801ХІІ. Відомості Верховної Ради України. 1993. № 4. Ст. 19.

${ }^{23}$ Конституція України : Закон від 28.06.1996 № 254к/96-ВР. Відомості Верховної Ради Украӥни. 1996. № 30. Ст. 141. 
discretion. Another provision of the Constitution of Ukraine enshrines the right of everyone to free access to information on the state of the environment, the quality of food and household goods, as well as the right to disseminate such information. The above information cannot be kept secret by anyone. This fully complies with the basic principles underlying EU legislation on access to environmental information, in particular the purpose of Directive 2003/4/EC. Based on Part 2 of Art. 50 of the Constitution, the right to access environmental information has three elements: it is the right to access information on the state of the environment, on the quality of food and household goods.

Information on the state of the environment is environmental information. The legislator, in adhering to this position, identifies the concepts of "information on the state of the environment" and "environmental information". On the one hand, there is a ban on taking certain actions on environmental information, on the other - there is a need to respect this right by any natural or legal person, as well as the state. Considering that the Constitution of Ukraine has the highest legal force, and laws and other legal acts are adopted on its basis and must comply with it, it can be argued that the provisions of the legislation of Ukraine, which set restrictions on access of citizens to environmental information, are unconstitutional $^{24}$. A characteristic feature of the right of access to environmental information, which distinguishes it from general information rights, is precisely the third element that excludes, under normal conditions, restrictions on environmental information. However, in conditions of martial law or emergency, in accordance with Part 2 of Art. 64 of the Constitution of Ukraine, individual restrictions on rights and freedoms may be established with an indication of the duration of these restrictions. The content of the above constitutional norms was reflected by the legislator even before the adoption of the basic law of Ukraine in the Law "On Environmental Protection". In particular, the provisions of this Law enshrined, among the basic principles of environmental protection, publicity and democracy in decision making, the implementation of which affects the state of the environment and the formation of ecological outlook among the population. Article 9 of the Law ${ }^{25}$ enshrines the right of every citizen to have free access to information on the state of the environment (environmental information) and the free receipt, use, dissemination and storage of such information, with

\footnotetext{
${ }^{24}$ Бойченюк I. Екологічна інформація та комерційна таємниця. Вісник екологічноі адвокатури. 2006. № 30. С. 12-16.

25 Про охорону навколишнього природного середовища : Закон від 25.06.1991 № 1264-XII. Відомості Верховної Ради Украӥни. 1991. № 41. Ст. 546.
} 
the exception of restrictions established by law; the right to participate in public environmental expertise, to obtain environmental education.

Publicly available information - any environmental information, with the exception of special environmental information, in turn, specific environmental information includes data reflecting the specific activities of individual central sectoral public authorities dealing with defense and national security issues, as well as subject to trade secrets, confidentiality and other data which the right may be denied in accordance with the law. The principle of remuneration, which may be applied by the relevant authorities in providing environmental information, however, the fee charged for such information may not exceed the cost of copying, retrieving and preparing information in one form or another, which is fully in line with similar provisions of EU law. Each State Party has undertaken to guarantee the right of access, receipt and dissemination of information to all environmental information subjects regarding the publication of environmental information, national and regional projects planned, national economic development programs and the rest. Such basic obligations of the parties fully reflect the purpose of Directive 2003/4/EC.

According to European environmental law researchers M. Anderson and A. Boyle, over time, some European Parliament and European Commission officials have sought to broaden the scope of information on EU environmental activities and to involve citizens and grassroots movements and groups in direct involvement in environmental protection. Catastrophes (such as Chornobyl) indicate what fatal consequences a lack of information can have ${ }^{26}$. A key element of an effective right of access to information is that stakeholders may not be particularly persistent in obtaining information.

Concerning the implementation of the Ukrainian legislation of the directives within the framework of the Association Agreement, it is worthwhile to note that the Ukrainian legislator should plan work on making the appropriate changes to the normative legal acts of Ukraine in order to ensure the functioning of legal instruments operating in the EU. The system of Ukrainian legislation does not contain a separate normative legal act or provisions regarding public access to environmental justice in the context of another normative legal act whose main purpose is the implementation of all principles of the Aarhus Convention and Directive

\footnotetext{
${ }^{26}$ Boyle A.E., Anderson M.R. Human right approaches to Environmental protection. New York : Oxford University Press, 1996. P. 25-42.
} 
2003/4. Access to information shall be foreseen, by leading rank, in accordance with the Law of Ukraine "On Access to Public Information" ${ }^{27}$.

Also, the legislation of Ukraine does not clearly define the concept of plans and programs in accordance with Directive 2003/35/EC, therefore it is advisable to take this into account in the relevant legislative act or acts, since the assessment of the environmental impacts of the implementation of plans and programs is one of the voluntary instruments for regulating environmental issues.

\section{CONCLUSIONS}

Basic principles of access to environmental information are enshrined in both Ukrainian and European legislation, ratification of a key document in the research area - the UN Convention on Access to Information, Public Participation in Decision-making and Access to Justice in Environmental Matters implementation of the provisions of the said Convention. However, the list of environmental information in the Law of Ukraine "On Environmental Protection" is narrower than in the Aarhus Convention and Directive 2003/4/EC.

The system of Ukrainian legislation lacks a separate legal act or provision regarding public access to environmental justice as part of another legal act, the main purpose of which is to implement all the principles of the Aarhus Convention. In Ukraine, the information component of environmental policy is extremely weak. It is obvious that the origins of the problem are concentrated in the absence of a system of environmental education and public education that should shape the ecological culture and public consciousness, thereby saturating the information space with this problem. Relevant central government and local government bodies, institutions of higher and secondary education, libraries, NGOs and the media can do much more to inform and raise public awareness of the state of particular natural resources and the environment in general. To do this, the state should formulate its own information, education and education policy in these matters and consolidate it at the legislative level by adopting a single consolidated legal act.

Against this background, it can be noted that the EU's environmental policy is seen as one of the driving forces behind the modernization of public administration in Ukraine. Within the framework of the Association Agreement between Ukraine, on the one hand, and the European Union, the European Atomic Energy Community and their Member States, on the

${ }^{27}$ Про доступ до публічної інформації : Закон від 13.01.2011 № 2939-VI. Відомості Верховної Ради України. 2011. № 32. Ст. 314. 
other hand, our country is required to borrow and implement extensive EU legislation in the field of environmental protection and environmental protection. Significant private and public investment in the industry. However, for the sustainable development of environmental legislation, in particular the right to environmental information, a careful harmonization with EU law is needed. This process should be selective and take into account local conditions, national interests and priorities.

\section{SUMMARY}

The article deals with the analysis of EU environmental legislation. It's essential to further improve and increasing the effectiveness of environmental legislation in Ukraine. An important step in this direction is the right of access to environmental information.

The author analyzes the application of the principle of participation and informing citizens in the legislation of Ukraine in accordance with the provisions of the Association Agreement with the EU. The Association Agreement with the European Union is aimed at securing and realizing the environmental rights of everyone. Every citizen has the right to free access to information about the state of the environmental information and the free acquisition, use, distribution and storage of such information.

The author emphasizes that Ukraine is taking steps to ensure that public authorities have environmental information, as well as create the conditions for further dissemination of such information through computer telecommunications or electronic technologies.

\section{REFERENCES}

1. Бойченюк I. Екологічна інформація та комерційна таємниця. Вісник екологічної адвокатури. 2006. № 30. С. 12-16.

2. Декларация Конференции Организации Объединенных Наций по проблемам окружающей человека среды 1972 г. URL: http://www.un.org/ ru/documents/decl_conv/declarations/declarathenv.shtml.

3. Добробог Л.М. Інформаційне забезпечення реалізації прав людини на екологічну безпеку. URL: http://www-history.univer.kharkov.ua.

4. Доклад Конференции Организации Объединенных Наций по окружающей среде и развитию Рио-де-Жанейро, 3-14 июня 1992 года A/CONF.151/26/Rev.1 (Vol. I). Нью-Йорк : Организация Объединенных Наций.1993. 519 с.

5. Дубовик О.Л. Экологическое право ЕС: формирование, развитие, достижения и актуальные задачи. Право и политика. 2004. № 12. C. 58-67. 
6. Конвенція ООН про доступ до інформації, участь громадськості в процесі прийняття рішень та доступ до правосуддя з питань, що стосуються довкілля (Орхуська Конвенція) : Міжнародний документ від 25.06.1998. URL: http://www.unece.org (ECE/CEP/43).

7. Конституція України : Закон від 28.06.1996 № 254к/96-ВР. Відомості Верховної Ради Украӥни. 1996. № 30. Ст. 141.

8. Кремер Л., Винтер Г. Экологическое право Европейского Союзу / отв. ред. О.Л. Дубовик. М. : Городец, 2007. 144 с.

9. Основи законодавства України про охорону здоров'я : Закон від 19.11.1992 № 2801-XII. Відомості Верховної Ради України. 1993. № 4. Ст. 19.

10.Правове регулювання відносин в сфері довкілля в Європейському союзі та в Україні / За заг. ред. В.Г. Дідика. К., 2007. 579 с.

11.Про використання ядерної енергії та радіаційну безпеку : Закон від 08.02.1995 № 39/95-ВР. Відомості Верховної Ради Украӥни. 1995. № 12. Ст. 81.

12.Про доступ до публічної інформації : Закон від 13.01.2011 № 2939-VI. Відомості Верховної Ради Украӥни. 2011. № 32. Ст. 314.

13.Про екологічну експертизу : Закон від 09.02.1995 № 45/95-ВР. Відомості Верховної Ради Украӥни. 1995. № 8. Ст. 54.

14.Про забезпечення санітарного та епідемічного благополуччя населення : Закон від 24.02.1994 № 4004-XII. Відомості Верховної Ради України. 1994. № 27. Ст. 218.

15.Про інформацію : Закон України від 02.10.1992 № 2657-XII. Відомості Верховної Ради Украӥни. 1992. № 48. Ст. 650.

16.Про охорону навколишнього природного середовища : Закон від 25.06.1991 № 1264-ХІІ. Відомості Верховної Ради Украӥни. 1991. № 41. Ст. 546.

17.Про ратифікацію Конвенції про доступ до інформації, участь громадськості в процесі прийняття рішень та доступ до правосуддя 3 питань, що стосуються довкілля : Закон України від 6 липня 1999 року № 832-XIV. Офіиійний вісник Украӥни. 1999. № 28. Ст. 2.

18. Степаненко В.С. Понятие и правовое значение принципов экологической политики ЕС. Политика и общество : Научный гуманитарный журнал. 2006. № 6. С. 83-93.

19.Угода про асоціацію між Україною, 3 однієї сторони, та Європейським Союзом, Свропейським Співтовариством з атомної енергії i їхніми державами-членами, 3 іншої сторони. URL : http://www.kmu.gov.ua/control/publish/article?art_id=246581344. 
20.Boyle A.E., Anderson M.R. Human right approaches to Environmental protection. New York : Oxford University Press, 1996.

21. Council Decision 2005/370 of 17 February 2005 on the conclusion, on behalf of the European Community, of the Convention on access to information, public participation in decision-making and access to justice in environmental matters Convention on access to information, public participation in decision-making and access to justice in environmental matters. Official Journal. 2005. L 124. P. 1-20.

22. Directive 2003/35/EC of the European Parliament and of the Council of 26 May 2003 providing for public participation in respect of the drawing up of certain plans and programmes relating to the environment and amending with regard to public participation and access to justice Council Directives 85/337/EEC and 96/61/EC - Statement by the Commission. Official Journal. 2003. L 156. P. 17-25.

23. Directive 2003/4/EC of the European Parliament and of the Council of 28 January 2003 on public access to environmental information and repealing Council Directive 90/313/EEC. Official Journal. 2003. L 041. P. 26-32.

24. Reference for a preliminary ruling from the Najvyšší súd Slovenskej republiky (Slovak Republic) lodged on 23 August 2010 - Jozef Križan and Others v Slovenská inšpekcia životného prostredia. Official Journal. 2010. C 301. P. 11-12.

25. Reference for a preliminary ruling from the Tribunal administratif de Paris (France) lodged on 12 November 2009 - Ville de Lyon v Caisse des dépôts et consignations. Official Journal. 2010. C 37. P. 29.

26. Request for a preliminary ruling from the Unabhängiger Verwaltungssenat Wien (Austria) lodged on 17 June 2013 - Ferdinand Stefan. Official Journal. 2013. C 274. P. 2-3.

\section{Information about the author:} Kachuriner V. L.,

$\mathrm{PhD}$, Associate Professor at the Department of State Law Disciplines, International Humanitarian University 33, Fontanskaya road str., Odessa, 65009, Ukraine 